of Practical Farmers of Iowa. Amer. J. Alternative Agric. 5:163-167.

23. Thornley, K., 1990. Involving farmers in agricultural research: A farmer's perspective. Amer. J. Alternative Agric. 5:174-177.

24. Workneh, F., A.H.C. van Bruggen, L.E. Drinkwater, and C. Shennan.
1993. Variables associated with corky root and Phytophthora root rot of tomatoes in organic and conventional farms. Phytopathology 83(5):581-589. 25. Wuest, S., B. Miller, R. Veseth, S. Guy, D. Wysocki, and R. Karow. 1994. 1993 Pacific Northwest on-farm test results. Crop and Soil Sci. Tech. Rep.
94-1. Washington State Univ. Cooperative Extension, Pullman.

26. Young, F., A.G. Ogg, Jr., and R.I. Papendick. 1994. Case studies of integrated/whole farm system designs: Field-scale replicated IPM trials. Amer. J. Alternative Agric. 9: 52-56.

\title{
LETTER
}

\section{Modern agriculture: Still agrarian-based}

In their excellent article on agricultural policy debates ( $A J A A$ 8(3):98-106), Beus and Dunlap make a couple of passing references to "modern industrialized agriculture." They join a host of persons who write in a similar vein.

They would be more empirically accurate if they were to refer to "partially industrialized agriculture." Even better would be to say that today's farming superimposes industrial materials and processes on a still-agrarian resource base. The industrial overlay has never really fused with the soil-water-organic nutrient base. Nor will it. The two are essentially incompatible, and the base remains agrarian.

A quarter-century ago, at an international conference held in Switzerland, renowned food technologists scratched each other's egos in predicting a bounty of synthetic foodstuffs to be derived from converting the hydrocarbons of fossil fuels into carbohydrates for human nutrition. The two or three of us economists were scorned when we warned about relying on a depletable resource for the world's food supply. The technologists were describing a truly industrial food system. Ours is not that.

I do not minimize the significance of our introducing industrial materials, primarily energy sources, into our farm and food system. I explored the subject in my article "The Three Economies of Agriculture," published in Journal of Farm Economics (August, 1962). The three economies were: 1) "producing primary products from that unique resource, the soil"; 2) production of livestock; and 3) "the long and complicated process of marketing." The marketing system is, of course, the most industrial of the three economies. Production of crops from soil has been the least so, butthe point of the article-in our century industrial materials and processes have been introduced, giving it a more industrial composition than it had previously.

In 1962, the livestock sector was at an intermediate level of industrialization. Since then it has become much more so, as huge cattle feedlots and hog operations that justify the term "factory" have given it a more industrial character.

In recent years I have written about the imminence of a shift backward from the industrial model, a shift forced by environmental concerns but much more by gradual depletion of the world's fossil fuel reserves. The turnaround will be dramatic in the livestock sector, where factory-style operations depend critically on inexpensive energy. Furthermore, there is no basic economy in feeding human food (corn, for example) to animals just to be able to eat ham instead of pasta.

Of more interest to readers of this journal is my observation that sustainable and other forms of alternative agriculture anticipate the swing I foresee back toward a more agrarian agriculture. What is so intrinsically distinctive about the agrarian base? First is its unique resource of the soil, which leads to an injunction to take protective measures lest civilization collapse. The crucial role of water as a conveyor of nutrients comes next to mind.
Less often recognized is another distinctive mark, the nonsimultaneity of processes in the growing of plants from which we get our crop harvests. The discipline of the seasons is the most familiar example, and it is imperious. Until all three features can be manipulated or made to disappear by pushing a button on a computer, our agriculture will continue to be only partially industrialized and, in a true sense, incompatibly so.

\section{Harold F. Breimyer}

Professor Emeritus

Department of Agricultural Economics

University of Missouri

Columbia, MO 65211.

\section{Letters To The Editor Invited}

The $A J A A$ welcomes letters, short or long, commenting on articles in this journal or sharing ideas likely to be of interest to other $A J A A$ readers. Since our space is limited, we do reserve the right not to publish all letters or, at times, to publish only excerpts from them. To take part in this exchange of ideas, write to: Editor, $A J A A, 9200$ Edmonston Road, Suite 117, Greenbelt, MD 20770-1551. 